Article

\title{
Land Grabbing in Europe? Socio-Cultural Externalities of Large-Scale Land Acquisitions in East Germany
}

\author{
Ramona Bunkus * and Insa Theesfeld \\ Department of Agricultural, Environmental and Food Policy, Martin-Luther-University Halle-Wittenberg, \\ 06099 Halle, Germany; insa.theesfeld@landw.uni-halle.de \\ * Correspondence: ramona.bunkus@landw.uni-halle.de
}

Received: 20 June 2018; Accepted: 10 August 2018; Published: 20 August 2018

\begin{abstract}
Recently, we witnessed an immense increase in international land transactions in the Global South, a phenomenon slowly expanding in northern industrialized countries, too. Even though in Europe agriculture plays a decreasing economic role for rural livelihoods, the increases in land transactions by non-local, non-agricultural investors pervades rural life. Nevertheless, the underlying processes are not yet well understood. Large-scale land acquisitions describe such purchases and leases in a neutral way, while 'land grabbing' expresses negative consequences for rural people. We investigate whether and under which conditions the term land grabbing is justified for the phenomenon observed in Europe. We propose six socio-cultural criteria that scholars should consider to come to an initial classification: legal irregularities, non-residence of new owners, centralization in decision-making structures, treating land as an investment object, concentration of decision-power, and limited access to land markets. We supplement our findings with empirical material from East Germany, where such land acquisition processes occur. Our paper contributes to the ongoing discussion about agricultural structural change in Europe, which is intensified by increasing land prices and a new distribution of landownership but likewise strongly intertwined with rural development.
\end{abstract}

Keywords: land grabbing; East Germany; socio-cultural externalities; rural development

\section{Introduction}

With large-scale land acquisitions (LSLA) increasing in pace and extent in the Global South over the last two decades, key issues of negative social effects for rural people have been widely studied [1-4]. LSLA in the Global South are often criticized especially for constituting an enclosure in the affected countries: Former (commonly) used land is regarded as underused or abundant, subsequently removed from the attached rural community, and handed to a new owner. Henceforth, there may be no access to ancestral community land which may have fulfilled other functions than food production. These enclosures may have political consequences too-they are described as 'neocolonialism' by some authors when former de-facto land rights are ignored [5-8]. Lacking a legal guarantee for de-facto land rights can even lead to dispossession of land-explored by scholars as a human rights problem [2,3]. Also negative consequences beyond these areas need to be considered $[9,10]$.

The fact that LSLA are accompanied by negative social effects for rural people is not, however, a problem which is limited to the Global South. LSLA is also increasingly taking place in other regions, for example Europe. We understand "Europe" in this paper not politically, but broadly as a geographic unit, comprising industrialized countries from the west and those with a post-socialist background-concisely as a western-oriented geographical economic area. The purpose of this paper 
is to emphasize that processes of LSLA with negative consequences occur also in the Global North. We picked Europe as an example for these processes.

Even though displacement, dispossession, or deprivation of livelihood for rural communities in the Global South cannot be mirrored in democratic industrialized countries, other negative effects can occur. Yet a clear definition of 'land grabbing' for those regions is missing. There are, however, various scholars who use 'land grabbing' as a synonym for the investments taking place, without thoroughly reflecting on what it means, for example in a European context [5,11-15]. We want to follow the research gap, formulated by Teklemariam et al. [16] (p. 783): 'Few works in the literature have set preconditions or criteria for labelling transnational land acquisition as 'land grabbing'.' This general critique is especially significant for considering whether, and under what conditions, the 'label' land grabbing is justified for the LSLA processes seen in Europe. Our contribution consequently presents an approach to the social consequences of LSLA affecting rural people in Europe; while not focusing on environmental effects.

How does the change of ownership relations influence rural life? To answer this broad question, another question must first be asked: whether the share of land owned and the number of land owners in a European rural region or village are actually responsible for well-being, which is understood as general contentment [17], and social freedom in rural places. Current examples of government policy presume that this is the case. The German government, e.g., in their latest agricultural policy report [18] outlined their policy aim of a broad distribution of land ownership-a goal for agri-environmental policy now being stated much more emphatically than at any time since the Second World War $[19,20]$. Close examination of the political argumentation shows that that broad distribution of landownership is regarded as a basis for the well-being of local economies and rural societies [18] —assuming that agriculture and rurality are intertwined [21]. Laschewski and Penker [22] (p. 2) supported that argument by emphasizing that property regimes have a significant effect on rural development: 'processes of rural change can be understood as processes of revalorization of rural property objects'.

There is not, however, much empirical evidence for the positive or negative impact of broad land ownership distribution. That is the conceptual research gap we aim to explore. To do so, we need to disentangle the relationships between land allocation, agricultural structural development, and the well-being of rural people. Accordingly, we discuss the activities in the land market against the background of the perception of rurality and what shapes and determines rural societies. These factors are undergoing change anyway due to the diminishing importance of the agricultural sector in the economy. Processes of structural change in agriculture and land concentration are underway even without large-scale investments in land but the increase of the latter intensifies this development. We aim to contribute to a sociological concept of 'land grabbing' in a European context. Therefore, we want to analyze if farmers remain embedded in rural communities and contribute to rural society even though there is agricultural land concentration intensified by LSLA.

In the following section, we will elucidate the concept of land values to show the broad implications this has on the changing of landownership (Section 2, based on literature review). Then we shall present the existing and extent of land grabbing worldwide and in Europe in particular (Sections 3 and 4 , also based on literature review). We will examine which factors justify conceptualizing a land transaction in a developed country as a land grab. Our field study in East Germany conducted in 2016 will also be considered, in which we investigated the link between social engagement and the identity of land owners, as well as analyzing rural interviewees' understanding of rural life and the importance of agriculture (Section 5). Having conducted this research, we make an attempt to advance the sociological concept of land grabbing in Europe by presenting six criteria for characterizing land grabbing in industrialized democratic societies (Section 6, based on literature review and case study). We discuss our results in the light of current social meaning and the possession of control over land and the broad trends of rural development in European societies, before we finally reach our conclusion. 


\section{Social Values of Land}

Owning and farming land encompass social elements, which can be a personal tie to the land as well as a symbolic meaning applying to national states [9]. This applies to developed as well as developing countries. In neoclassical economics, land is treated as a commodity with a certain market value, where the public interest and the social appreciation of land are hard to include. However, it is only when we understand what makes land (and its cultivation) precious for society that we recognize the additional values that can be taken away or 'grabbed' from a land user and from rural people.

The European Union defined farming as including rural landscape management: 'Agriculture is the main land user and the resulting high visibility leads to a widespread perception that rural matches with farming' [23]. Thus, agriculture is considered to be closely linked to rural livelihood and to fulfil additional social-cultural functions besides food production. Sowing, harvesting, and processing are likewise culturally embedded into rural societies and celebrated with feasts like harvest festivals, in German 'Erntedank'. Laschewski [24] (p. 17) stated that the agriculture-rural discourse highlights 'agriculture's ecological and social, local embeddedness'. In the justification of the Common Agricultural Policy (CAP) farming is described as land use which provides multifunctionality to the societies [21]: its output is thus stated to be a public good and consequently affecting rural development.

Alden Wily [25] observed that in contrast to actual land use, landownership is a social construct. Landownership is meaningful for state-building as well as economic development. Other studies highlighted that land ownership creates a social value by empowering people [26,27]. In a developed country land ownership brings powers of decision-making and control decisive for rural development and well-being. All these social values are lost by land grabbing.

There are different types of ownership which are closely connected with assigned bundles of property rights [28]. Property rights are considered to be social relationships regarding natural resources, as they are arranged and bargained amongst people [29]. The land user, thus the tenant, has rights to access and withdrawal [28]. The tenant may have long-term or short-term rights to the land. The person (or group) with full property rights is the land owner, who can sell the land or inherit it and also decides who can lease the land. It is expected that people with full property rights, thus the land owners, treat the land more sustainably [29,30], but also long-term users with secure rights [31] are likewise expected to spend more time on social engagement and invest in collective action as they act in longer time-horizons [32].

Moreover, land has a symbolic meaning and promotes a sense of identity. Identity can be connected to a place or to a way of life, because representations of oneself can be transferred into objects or manifested in narratives. The loss of identity could be intertwined with the loss of a landscape or the ability to farm a specific piece of land, because the own self-representation would be at stake and the narrative interrupted. Consciousness about own identity can also be gained by differentiation (e.g., distinction of village or land in comparison to the neighboring village) as well as by coherence (e.g., meaningfulness of one's own work or community) [33]. Wars have been fought over land and domestic landscapes are referred to as home. In the U.S., Salamon [34], describes rural societies struggling with processes of suburbanization, in which they lose their identity. Local knowledge, once a privilege of local residents, provides a sense of agency. If new actors are shaping landscapes, agency is no longer in the hands of the locals, and they lose identity.

Verderey [35] described in her book The Vanishing Hectare the privatization of land in post-socialist Romania. She particularly documents the people's sense of entitlement to former collectivized land, which also consists of personal claims. Even though marks of land plots are gone, former owners and other claimants try to recover their piece of land. This shows, that there is indeed an emotional bond to the land, likewise described for East Germany where after reunification expropriated land owners who did own over 100 ha and were not resituated tried to get hold of their former property, not purely for economic reasons as described extensively by Bromley [36]. Preissel et al. [37] show that economic interests are not of foremost importance for cultivating land in Northeastern Germany: Farmers like to 
invest in soil management and long-term development instead of generating high yields immediately. Petrescu-Mag et al. [38] (p. 174) speak of the cultural significance of land and claim that Romanians 'value land as a symbolic and material ground on which the state produces and reproduces itself'. Thus, the feeling of connectedness and its importance for identity are additional social values of land for consideration in what can constitute land grabbing in developed countries.

There are no definite numbers to define "large-scale". According to Common Agricultural Policy by the EU, small and medium-sized enterprises are up to 95 hectares; a large-size enterprise would thus have more than 95 hectares [18]. In general, we define "large-scale" as a relatively big proportion of available land. When focusing on social outcomes of large-scale agriculture, which is supported by a land ownership concentration process, an important sociological discussion about negative outcomes of industrialized agriculture has to be mentioned: The idea that large-scale farming can have adverse effects for rural communities stems e.g., from the research of Goldschmidt [39] who studied three communities in California in the 1940s. He found that the industrialization of agriculture leads to an urbanization of rural communities and thus a change in the interpersonal relationships of rural inhabitants. Extensive studies in the following decades either confirmed or discarded the Goldschmidt-Hypothesis [40,41]. A recent macro-level study about rural Canada [42] tried to transfer the findings into contemporary agricultural structure and rejected the thesis that areas with large-scale agriculture possess worse socioeconomic conditions than those which are family farm dominated. Yet, our study is not targeting the macro-level, but the perception at a regional level.

Furthermore, large-scale land acquisitions are not limited to the purpose of agricultural production: Acquisition of areas for wildlife protection, environmental protection, ecosystem services or mining take place globally as well [43,44]. Fairhead et al. [43] connected this appropriation of land with the theory of 'accumulation by dispossession' by Harvey [45] in which he stated that capital accumulation processes would be fueling class differences and eventually lead to an enrichment of the proprietary classes. Fairhead et al. [43] argue that by this theory, nature is not only a commodity, but transformed into an asset, for example with the idea of ecosystem services. Natural processes would be reinterpreted as the creation of assets for new markets, for example the natural carbon sink potential of trees can be used for $\mathrm{CO}_{2}$ certificates in emissions trading. In the end, the rich would be the ones who could afford to privatize; even if the acquisition would be a "green" transaction to protect wildlife, for example. Transferred into the context of agricultural land, there is indeed an indication that the land is sold to those who have capital available.

\section{Understanding Land Grabbing}

Worldwide the trend of foreign and domestic actors securing large tracts of land for mostly agricultural production has increased substantially in frequency and extent $[2,3,8,46-50]$. Based on the latest figures from the Land Matrix (accessed February 2018), the area of completed transnational as well as domestic deals is 50,257,227 ha [51]. The liberalization of land markets has made it possible to buy or lease land around the world. The buyers and long-term lenders-the investors-are often states and multi-national companies. Next to profit maximization, food provision can be a concern of investors from countries with poor soils and adverse hydrological conditions. Likewise, land became an interesting target for investors with a non-agricultural background after the food crisis of 2007-2008 [49], as can be seen by the fact that only $20 \%$ of the transferred area has been cultivated [9].

Land acquisitions and land concentration processes can result in land grabbing, but do not necessarily do so [52]. There can be positive outcomes like more cost efficiency of production, productivity, employment, and a good infrastructure [47,53].

Socially negative consequences that are widely cited include a widespread loss of employment, expropriation, displacement, or social unrest. Only when such negative consequences occur should we apply the notion of land grabbing [54]. The 2011 Tirana conference of the International Land Coalition defined land grabbing as land acquisitions that are in violation of human rights, without prior consent of the preexisting land users, and with no consideration of the social and environmental 
impacts [54]. Well-studied cases occur mostly in the Global South where so-called 'underused land' is given to investors who expel the rural population from their land $[1,46,49,55]$. Social organizations embraced and captured the issue once it was identified, less than a decade ago, denouncing land grabbing [54,56,57].

Insights from the literature point us to various social aspects of LSLA. One important aspect is the emergence of enclosures, created by restricting the local population's access to land they had traditionally used, perhaps as a common, as a key to community life [6,50,58,59]. Ince [6] (p. 105) links, 'capitalism as an irreducibly colonial formation with global inceptions' to contemporary land grabs. This leads to the critique that land is treated as an asset, degraded to simply an item of a portfolio. New landowners might not realize the complexity of land but focus on a single value, like market value [26]. The commodification of land is particularly caused by new, institutional landowners, like pension funds or hedge funds or private equity firms [5,60]. McMichael [50] (p. 51) pointed out that modern agribusiness treats 'land as an economic resource rather than as socioecological wealth', assuming that in this mode of production utilization is more important than sustainability.

Issues of human rights come into play, when rural societies are affected by displacement and expropriation. Irregularities like corruption appear and lead to greater disparity in power relations $[2,8,59]$. Makki [59] noted that expulsion or relocation of inhabitants erases cultural practices, collective memories, and social ecologies.

Thus, an analysis of whether a particular case of land acquisition turns into a land grabbing has to be based on multi-criteria analysis of the output and long-term results. This requires first a debate about how to define such criteria, which researchers are just beginning to explore for the European context. Some authors have developed new sociological concepts of land grabbing our study can draw upon. Friis and Nielsen [61] (p. 18) described a shift in land grabbing research from focusing on hectares and the power of foreign actors to examining 'the distribution of power and agency between local and foreign investors, smallholders, middlemen and state authorities.' In that regard the definition from Borras Jr. et al. [62] (p. 850) is significant, stating that land grabbing is 'essentially control grabbing' - meaning grabbing the power to control land and other associated resources in order to derive benefit from such control. Both studies point out that LSLA, and land grabbing, can be subtle. We see benefit in combining these definitions with the theoretical 'powers of exclusion' framework by Hall et al. [63], who talked about four aspects of the power of exclusion, namely: (1) regulation, (2) force, (3) legitimation, and (4) market power. These mechanisms can lead to less access to land, and represent land grabbing. We propose to conceive of land grabbing as control grabbing further defined by various kinds of power of exclusion particular by legitimation and market power.

\section{Land Grabbing in Europe}

Which of the aforementioned negative externalities of LSLA apply in a European context? Agriculture provides a workplace for only $4.4 \%$ of employed persons in the EU [64] and only a minority of people depend on access to land to sustain their livelihoods. Further, the legal irregularities familiar in the Global South are presumed to not occur there to this extent due to an institutional environment ranging from land registries to conflict regulation mechanisms. Is the term land grabbing misleading in the context of developed countries, since so many implications are different or are there commonalities?

In the study Extent of farmland grabbing, land grabbing in Europe is treated as a fact, measured by 'the degree of foreign ownership of land, the capturing of control over extended tracts of land and by the irregularities that have accompanied various land transactions' [60] (p. 11). The study argues that the impacts of farmland grabbing must be placed within the context of broader structural changes within EU agriculture (p. 11). Kay et al. [60] further argued that farmland grabbing would be a limited phenomenon in Europe compared to the processes in Africa or Asia. They present data, based on various sources including Land Matrix and anecdotal evidence, about Romania, Bulgaria, Hungary, Poland, Slovakia, Czech Republic, Lithuania, and Latvia. Thus, mainly former transition countries 
are involved. The Transnational Institute has published a collection of case studies about European land issues [13]. According to those studies, the reasons for the rush to buy farmland in Europe are investment opportunity due to low interest rates, relatively cheap land prices (but prices that local small-scale farmers cannot afford) and the EU area payments. The latter are decoupled from actual land cultivation, which means that large farms are subsidized according to their size [13].

Another driver of land deals is the willingness to change existing arrangements on the part of current owners. For example, in East Germany shareholders of agricultural cooperatives might want to sell their share when they retire. The cooperatives might need outside investors, who can pay off the shareholder. Moreover, it can be problematic to find a successor for existing agricultural enterprises: If there is an heir, he or she might still not be interested to continue farming and thus the land is sold [65].

Good data is lacking on LSLA in Europe. It appears that Europe faces land concentration, but there is no reliable data about the scope of LSLA [66]. The Land Matrix Global Observatory [51] includes only deals over 200 ha and made in severe economic situations-only 155 out of 1520 listed deals are in Europe (Access date 22 February 2018, omitting deals in Russian Federation). Qualitative case studies on the effect of land concentration pushed by further investments for the rural societies, can rather be found on post-socialist European countries $[11,14,67]$ and only to a minor extent on Western Europe, for example Germany [68], or Scotland [32,69]. Scotland faces a high land concentration fueled by the history of feudal structures.

Nevertheless, there is available data about land prices, which shows a driver behind large-scale land acquisitions: The land prices of East Europe are much lower compared to those in West Europe. For example, a hectare in the Netherlands cost in 2016 on average 63,000 $€$ compared to $1958 €$ in Romania; the rent was $791 €$ per hectare in the Netherlands in comparison to only $46 €$ per hectare in Latvia [70]. Even though the regions differ in soil quality and infrastructure, the prices are also shaped by national economies. Within the European Union there is a free internal market which also enables land acquisitions [60], this allows buying and selling land across countries. Thus, a hectare in Romania would be very cheap for a Dutch buyer, but for a Romanian farmer who already witnessed an increase, this would not be cheap at all. What all European countries have in common is that they face rising prices for their lands because of the increasing global demand for land.

\section{Case Study and Empirical Method}

We now turn to East Germany for a more in-depth examination of LSLA in Europe. We provide a short historical background on the relation of rural societies and agriculture in East Germany. For context, we outline the phenomenon of ongoing agricultural structural change and the East German land market as regards development of both sales and lease prices. Thereafter, we present our case study design and empirical methods. East Germany is a former transition country which embodies institutional arrangements of "West" Germany. Thus, it can serve as a bridging example between East and West, as a western-oriented geographical economic area.

\subsection{East Germany's Agricultural Structure and Land Market}

East Germany is a special case, as it reunited with West Germany resulting in a combination with a legacy of socialist land tenure system, agricultural farm structure, and characteristics of rural societies being exposed to the adaption to a prosperous state and the transfer of institutions. As stated by Swain [71], until today, the former German border still marks a change of agricultural landscape: smaller fields in the west and larger fields east of the river Elbe which show that there is indeed a difference in farm structures and cultivation. The role of agriculture for society in East Germany cannot be understood without looking at the recent history of the German Democratic Republic (GDR) times and their particular agricultural model. During the GDR, collective agriculture was of foremost importance and shaped the social relationships and jobs in rural areas. Jochimsen [72] stated that in the GDR's planned economy the purpose of agricultural cooperatives, so-called LPGs (In German: 
Landwirtschaftliche Produktionsgenossenschaften), was to supply the region, not to produce for a market. Next to food security, the role of agricultural cooperatives was to replace squire and church. The LPG's fulfilled social functions were assigned to the municipality in Western Germany's Federal Republic. The manufacturing industry was attached to the LPGs and the agricultural cooperatives created a social network. Successors of former LPGs partly still operate as personal partnerships or legal entities [73] (with 'legal entities' we describe the German juristische Person, which includes for example limited liability- or stock companies. It refers to public law as well as civil law [74]) or because there were no other alternatives to rent out their land. Further, for a long period, high percentages of previous cooperative members decided to sustain the successor farms [75], due either to the social acceptance of these farms amongst the population [72] or because there were no alternatives. Thus, particularly in the post-socialist European countries like East Germany, we start from a legacy of a close connection between agriculture and social life in rural areas.

With the German reunification and the progress of industrialization in agriculture, numerous jobs in East Germany's rural areas were lost, including soldiers who were no more needed after reunification. Nowadays, the weak rural economy leaves a relatively high number of people dependent on transfer payments [73]. In 2016, East Germany still had a higher unemployment rate (9.4\%) than West Germany (6.2\%). For 2003-2012, rural unemployment for East Germany amounted to $13.5 \%$ compared to West Germany with 6.3\% [76,77]. The villages and the agricultural sector are no longer central for employment, jobs are mostly in the cities and agriculture's share in both the economy and employment decreased [78]. In 2014, only 1.4\% of the German work force and 2.2\% in Saxony-Anhalt in East Germany-our study region-was employed in the agricultural sector [64].

In our study, drawing on Specht et al. [79], Knickel [80] and Chavas [81], we define structural change in agriculture as a long-term transformation in such structures as farm units, farm size, people employed in the agricultural sector, and structurally-induced changes in cropping patterns and land use. These developments are connected to peripheralization, which means the decrease of rural infrastructure [82] and rural-urban migration [83].

In Saxony-Anhalt, the federal state in East Germany where we conducted our field study, there are 4200 farms with an average size of 277 ha [84]. Table 1 shows that in East Germany the farms organized as legal entities make up $15.2 \%$ of all farms (due to the legacy of restructuring the former LPGs there is still a much higher percentage of legal entities, compared to the German-wide average where this group only represents $2 \%$ of all farms), yet cultivate about half of the agricultural area. In Saxony-Anhalt, the concentration processes follow that pattern: in 2013, 13.3\% of the farms were legal entities and cultivated $44 \%$ of the agricultural area [18]. Further, at the upper level in Saxony-Anhalt $6 \%$ of the farms cultivate $39 \%$ of the agricultural area [84], an indicator of land concentration.

Table 1. Agricultural enterprises in Germany. Based on [18,85].

\begin{tabular}{ccccc}
\hline & \multicolumn{2}{c}{1999} & \multicolumn{2}{c}{2013} \\
\hline Legal Form & $\begin{array}{c}\text { Average Farm } \\
\text { Size (ha) }\end{array}$ & $\begin{array}{c}\text { Number of } \\
\text { Farms (in 1000) }\end{array}$ & $\begin{array}{c}\text { Average Farm } \\
\text { Size (ha) }\end{array}$ & $\begin{array}{c}\text { Number of } \\
\text { Farms (in 1000) }\end{array}$ \\
\hline $\begin{array}{c}\text { Individual enterprise } \\
\text { (main and sideline) }\end{array}$ & 60.3 & 21.8 & 87 & 17.1 \\
$\begin{array}{c}\text { Personal partnerships } \\
\text { Legal entity }\end{array}$ & 420.2 & 3 & 373 & 3.3 \\
Total & 1160.5 & 3 & 768 & 3.7 \\
\hline
\end{tabular}

In general, the number of farms has decreased while the size of farms has increased. Between 2010 and 2013 the total number of farms decreased in Germany by 5\%, and between 2013 and 2016 by an additional 3\%. In total there are 13,000 fewer farms [86]. Similarly, at the European level we find a decreasing number of farms with increasing average farm size $[60,87]$. These numbers do not however depict how much land is owned by the agricultural enterprises and how much is leased. The share 
of leased land in East Germany is continuously declining, with $71 \%$ in 2013 compared to $90 \%$ in 1993, yet is still comparatively higher than in West Germany where the trend is opposite, with 55\% of the agricultural land in leasehold in 2013 compared to $40 \%$ in 1993 [18,85]. By "large-scale land acquisitions" we mean when a vast amount of land is sold at once. There are as well no definite numbers, but the lot size of the German Land Administration and Privatization Agency BVVG could serve as a benchmark. It was criticized that the sold land was often too large for farmers and thus attractive for investors because they could provide the money [88]. As a response to German policy and for further preservation of the BVVG (as it would lose its purpose by selling all state land), the lot size was reduced from 25 to 15 hectares [89]. Nevertheless, these numbers are not binding for the selling of private land. If the relevant authority accepts a land deal, a larger land size can be sold. Farms with thousands of hectares become possible by buying large-scale enterprises [90]. It should also be noted that large-scale farms do not necessarily own all the land, but they can lease large parts.

The prices for agricultural land are rising worldwide as well as in European land markets [11]. Land prices have risen in Germany: from 16,500 Euro/ha in 2007 to 25,189 Euro/ha in 2013 in West Germany and from 4200 Euro/ha to 10,510 Euro/ha in East Germany over the same period [91]. Likewise, land lease prices have increased in recent years (BMEL 2015). Even though prices are rising, numerous land transactions have still taken place, leading to an increase in concentration in ownership and tenancy. There is debate over how far the current trend of land concentration is driven by investments from buyers with a non-agricultural background, which tend to accompany major increases in land prices [68]. Tietz [92], e.g., stated that a noticeable amount of agricultural land goes to these new owners via share deals-possible with the organizational form of cooperatives and stock companies. Scholars further qualify this argument by noting that such deals are not the only reason for the increasing prices of agricultural land $[65,68,93]$.

\subsection{Data Collection}

To propose a sociological concept of 'land grabbing', we supplement categories which we derived from a literature review and with empirical material from a case-study in the East German's federal state Saxony-Anhalt. We conducted the study in the districts Altmark and Salzlandkreis (see Figure 1). Both have a different soil quality and are about $115 \mathrm{~km}$ distant from each other.

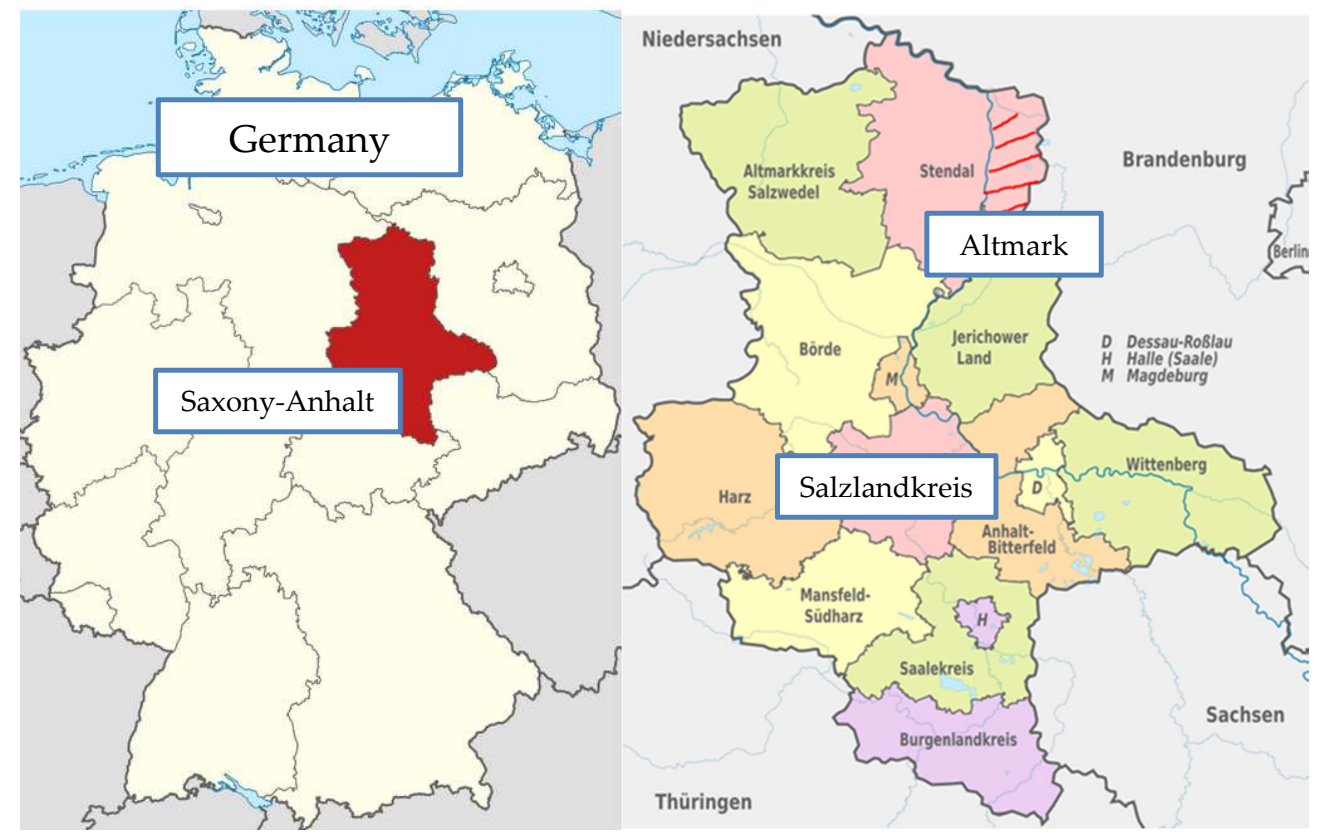

Figure 1. Situation map of Saxony-Anhalt and the study areas. Source: adapted from [94]. 
We visited four villages between July and December 2016. The case study design represents two contrasting village types: two villages with a broad land ownership and lease distribution as well as various farms with their place of business and family home, in the village; and two villages with, in contrast, rather concentrated lease and ownership structure.

We conducted 16 qualitative interviews with locally based and engaged farmers who became known by online business directory, but the rather hidden characteristic [95] of our population of being locally engaged can only be named by other farmers. Thus we used chain-referral-sampling relying on advice from already interviewed farmers. These were semi-structured in-depth interviews [96]. We considered the chain-referral-sampling to be a suitable sampling method for our purpose. We needed to find experts who could give us insights into the topic of farmers' engagement and land acquisition. There was no sampling frame, that is a full list of local experts or farmers to choose from, partly due to German and European data protection and privacy laws and partly due to specificity of data we needed. We told a potential interviewee that we had already spoken to farmer $X$, and we could see from the change in the interviewee's reaction that this was sometimes a reason why an interviewee agreed to the interview. We also contacted some interviewees without a referral, based on our growing knowledge as we became increasingly familiar with local networks during the research [97]. We continued with the interviewing until we covered most of the local farmers and reached saturation in data, that is when no more significantly new information could be expected with a new interviewee. As a result, by the end of the field research we covered a large portion of farmers in the area in all four villages.

We interviewed 135 rural people with a standardized survey who were met at public places in the villages of which 127 questionnaires could be used for analysis. We only included interviews with local inhabitants who live not further away than $30 \mathrm{~km}$ and are also villagers. Because the interviews were only possible with people who were outdoors at that time, the sample is non-random, but nevertheless the researcher tried to achieve quota sampling [97] by approaching villagers of certain age levels or gender; still, the data does not display a representative cross data for Germany. The sample represents 52 interviewees from villages with broad land ownership distribution and 75 interviewees from villages with rather concentrated lease and ownership structure. Likewise, the sample represents 28 landowners and 99 non-landowners. Of these small-scale landowners (on average 6 ha), 95\% rent it out to farmers. The survey consisted of 59 questions mainly with multiple-choice option, but also several open questions. We elaborated our main questions based on the scholarly rural development discussion where farmers remain embedded in rural communities and contributing to rural society, in a way that could be threatened by agricultural land concentration [98].

From a rural people's perspective, the focus of the empirical study is to explore how and in what degree, land ownership, agriculture, and rural life are perceived as important. We aim to shed some light on how these spheres are interlinked, e.g., whether land ownership makes a difference in how people farm and whether rural people recognize the importance of farming for their village. From the farmer's perspective, we equivalently asked farmers how they judge their individual engagement into village social life, and if their engagement in general is influenced by the share of land they own. The goal is to examine assumptions that socially embedded farmers are important for rural society and that a certain share of landownership implies a connectedness with the rural region. That then allows us to draw conclusions on what the social-cultural implications of land grabbing would be. According to Bryman [97], qualitative studies are suitable for moderatum generalizations, which are of a different nature to quantitative generalizations. Moderatum is used in contrast to total generalizations, which can be problematic from an epistemological point of view when a specific statement should be covered by the general laws. According to Mayring [99], moderatum generalizations mean to specify the extend of generalizations. When keeping in mind their limitations, they can nevertheless lead to insights by finding parallels with comparable studies. Thus, we use our case study for moderatum generalization in line with insights from our literature review. We are aware that the amount of studies about LSLA in Europe is also limited, but we consider it a starting point for further research. 
When proposing our criteria to identify land grabbing in Europe, we supplement our own East German case study with qualitative case descriptions found in the literature, in order to see whether our initial way of depicting socially negative consequences of LSLA holds for a larger European scale. We want to illustrate the patterns of contested agricultural land in Europe, which is not homogenous itself, but may also have similarities to the patterns in the Global South.

\section{Results: Six Criteria of Land Grabbing in Europe}

What factors justify conceptualizing a land transaction in a developed country as a land grab? We subdivided our findings into six empirically grounded criteria. Not all six of them have to be applicable at the same time to speak of land grabbing, but they are strong indicators that there are negative occurrences around LSLA. Approaching a stage of land grabbing could justify political intervention in order to safeguard and guarantee social wellbeing in rural areas.

\subsection{Legal Irreglarities}

Our first assumption is that, although we deal with countries such as Germany with a working legal system, plus a high share of trust in government and the rule of law [100], there can be irregularities with land contracts that should serve as a criteria of land grabbing. New actors bring 'extra-economic forces' [15]. Those are described in the EU study as '[ . . . ] special conditions offered by state-apparatuses (at national, regional and/or local level), good political connections, full support of administrators, and the practice of 'skirting the law', such as 'pocket contracts' in Hungary' [60] (p. 50). The term 'pocket contracts' in Hungary 'originally referred to land deals that omitted the date of the purchase, and the contract is kept 'in the pocket' until the land transactions moratorium (which restricted the deal) is lifted. Only then is the date filled in and the contract legalized and submitted to the land-registry authorities. The term is now used to describe a diversity of contracts that aim to find 'solutions' to legal restrictions on land deals' [67] (p. 132).

In Germany, former owners who possessed below 100 ha during GDR times and had been expropriated between 1945 and 1949, have been allowed during several rounds of land reform and land privatization to buy back parts of their original land (in ideal boundaries) for a reduced price from the Land Administration and Privatization Agency (BVVG). The latest amendment to the land purchase program from 2011 gave a final deadline for those favored sales. There is anecdotal evidence in our case study that in the light of current high land prices in Germany, non-agricultural investors tried to find those former owners, offering them money to buy back their land, and asking for similar kind of pocket contracts, to transfer ownership to them after the moratorium on resale, a condition to these favored sales, had passed.

\subsection{Non-Residence of Landowners}

The underlying question of this criterion is whether resident farmers invest more into social involvement and civil society than non-resident farmers. In East Germany farmers are not equivalent with landowners, given the high percentage of leaseholds. Under the circumstances of ongoing land concentration, the question is whether land owners engage differently in local communities depending on residence.

Most of the investors with a non-agricultural background in East Germany operate from outside the region, though few are from outside Germany: a quarter of them are from other East German states. A study that compared the distance between the registered agricultural headquarters' address and registered shareholders' place of residence (defining residence as within a commuting distance of $50 \mathrm{~km}$ ) found that only $9 \%$ of out-of-region investors are from other European countries, the majority $(67 \%)$ come from West Germany and a share of $24 \%$ are from the East German states themselves [92]. Forstner et al. [101] identify investors as those who own the majority of the share of an enterprise, and distinguish them from other shareholders. Tietz [92] (p. 62) pointed out that what is important is neither the origin of capital nor the headquarters location, but the way the revenue is used and how 
this is connected to rural areas and other farms. Some investors like to show their engagement for rural societies in form of sponsoring. For example, KTG Agrar, the largest agro holding in Germany which went bankrupt in 2016 [102], displayed its engagement to local sport clubs in Oranienburg, where the company had an office [103]. In order to better identify the benefits or losses for a community, there is a research gap on the total share and the regional spread of the actual activities of these investors and whether those differ depending on their agricultural background.

The former agricultural ministry of Saxony-Anhalt, which was in charge until 2016 regarded the land ownership structure as crucial for social embeddedness and stated in several press releases that a broad ownership structure should be ensured to prevent market power by few investors. This means that lesser big and influential landowners are desired, but rather local, small landowners who are supposed to have a closer bond to their land. The ministry proposed a law aimed at restricting farm size in land deals of both sales and leases (The agricultural ministry of the federal state Lower Saxony also plans a similar law after 2016 [104]). Rural inhabitants were assumed to be 'tied' to the countryside if they own land [105]. There is further the claim that enterprises actually engaged in farming have a prime interest in taking social responsibility at their operating site, and supporting the local communities. Moreover, landowners feel even more connected to their village if they own land there.

Information from our field study supports the assumption that owning local agricultural land can lead to a closer tie to the community. A resident farmer of a medium-sized enterprise argued that one only engages in local social activities if the center of one's life is there, too. Another interviewee stated that she considers herself a resident farmer because she 'lives here, works here, is engaged in the rural community including clubs and starts a family.' Our data also indicates that landowners are more tied to the village. Only 14 out of 128 respondents answered, that they considered leaving the village in the next three years. We divided the respondents into the group of landowners and the group with no landownership. Landowners are considered to be owners of agricultural farming land, excluding houses, extended gardens or allotments. Figure 2 shows that, respondents who own a piece of land answer less often that they consider leaving (14\% compared to $23 \%$ ). Yet this group difference is not statistically significant and many other factors influence migration, predominantly the search for employment.

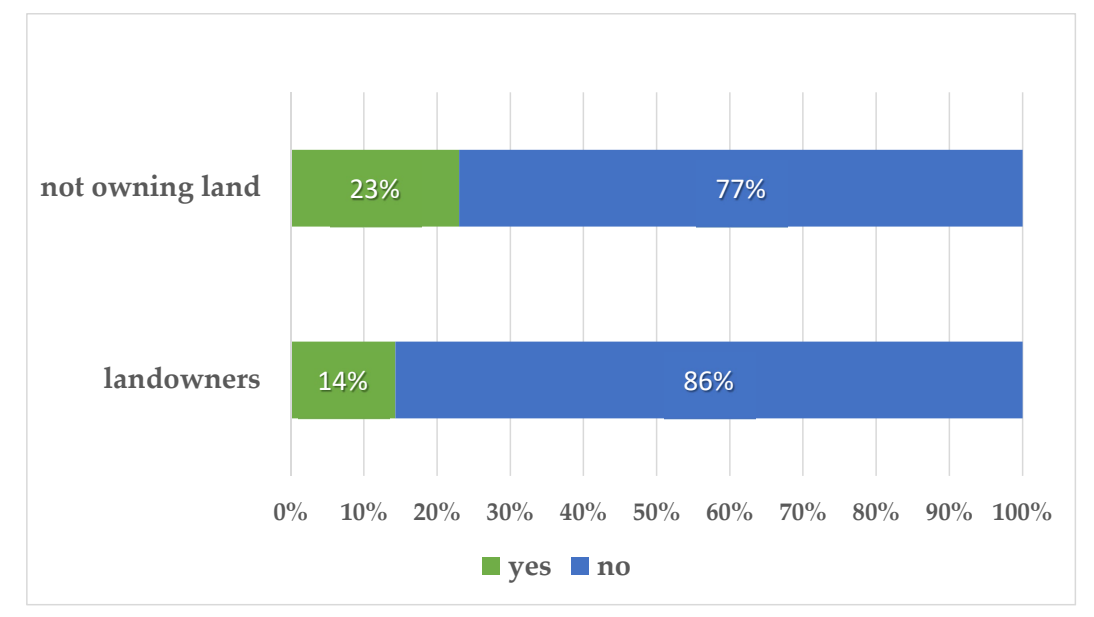

Figure 2. Would you consider leaving your village in the next 3 years?

Our study indicates that there is, however, considerable complexity to the issue of residence: Large farms' fields are typically spread among more than one village even though one village is the main place of business. Our interviews with farmers point out that they do not necessarily call their place of business their home. They try to bring social involvement to all places of operation, but there is an unequal distribution: The location of the farm headquarters is the main place that 
profits. Several interviewed farmers mentioned that they help by shoveling snow in winter or with construction work at the village sports field. We assume, with bigger land-holding structures and fewer farm headquarters, fewer communities can benefit from famers' engagement.

Non-residence of agricultural investors can lead to various social tensions. In one of our case studies, an investor who rented land was marginalized by a group of private landowners who prohibited their tenants from swapping plots with him. This resulted in a disadvantage for all agricultural producers as they had only little leeway to conduct the swaps that were common.

Residency also influences whether rural people are aware of agriculture. In our study, only $6.1 \%$ of interviewees in East-Germany associate agriculture with rural life. We measured the connection between farm owner residency and awareness of agriculture by asking villagers the number of farmers they could mention. In all villages (including districts) there were at least three farm headquarters. We found that in the village with the highest density of farms, more villagers were able to name a farmer. When asked to name up to three farmers or enterprises, $50 \%$ of the respondents in that village could do so (Altmark 1) (see Figure 3). In the villages with higher land concentration and distinct agricultural structure, only $27.5 \%$ of the interviewees named three farmers on average.

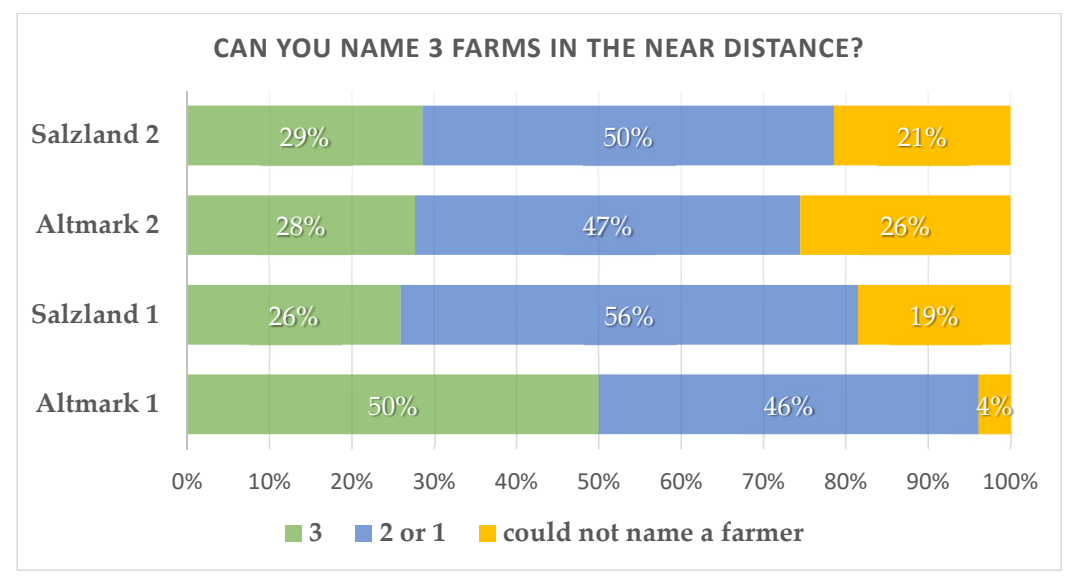

Figure 3. Please name up to three farmers in the near distance.

This also shows, if the headquarter is not local, villagers would not recognize it. Another question indicated that people in rural societies with a higher density of resident farmers and an underlying broader distribution of agricultural land ownership, find agriculture more important for their village. On a 1 to 5 scale, $65.2 \%$ of the interviewees in our study in the village with the highest density of farms found agriculture to be 'very important', opposed to $39.2 \%$ on average in all other villages together.

\subsection{Centralization in Decision-Making Structures}

Centralization in decision-making structures also means centralized decisions in production processes, which automatically leads to standardization of production processes. With land concentration, huge tracts of land are controlled by a small number of people. Large-scale agriculture changes landscape aesthetics because monoculture starts to dominate [15]. Further van der Ploeg et al. [15] (p. 9) argued that the large tracts of land (and extended herds) require a standardization of the production process; which greatly increases the use of chemical inputs and preventive medicines. They referred to a case in Romania where about 99 people farm 12,000 hectares. Nevertheless, labor requirements depend also on the farm animal, crop or production system. It does not necessarily follow that large-scale farming has relatively few workers. Kay et al. [60] gave examples of land degradation in Europe, which they connected to large-scale agriculture: improper application of manure, greater ploughing for energy crop cultivation, and the disadvantages monocultures have for 
wildlife. We want to add the aesthetical-cultural dimension which shapes the countryside, for example by large-scale greenhouses in Spain or the Netherlands.

Even if individual farm entities are kept, the whole company is managed centrally and more management decisions are taken from a distance. Distance from the local problems does not allow for adapted, specialized solutions and also does not allow for local people's engagement in the processes [106]. Mamonova [14] pointed out in her case study in Ukraine that rural inhabitants were not fond of monocultures and the uses of pesticides; which we argue might increase due to centralization in decision-making structures. Rural inhabitants might become less involved with the landscape around them. Moreover, agricultural cultivation should not be regarded as the only form of land use [25]. Interestingly, our field study illustrates an aspect of this disengagement, too.

In Saxony-Anhalt, 38.1\% of interviewees name at least one agricultural connotation when asked about soil. Yet we found a statistically significant difference in what landowners and non-landowners associate with the term 'land'. Interviewees who own land associate more often positive notions with 'soil': A share of $42 \%$ cherish 'fertility', or 'high quality', versus only $25.4 \%$ of those who do not own land. In total $57 \%$ of landowners mentioned agricultural terms versus $34 \%$ of those who do not own land. This shows that rural people do not necessarily think about agriculture when asked about soil, in contrast to landowners who are more engaged in this topic. It likewise illustrates the distance between agriculture and rural people, due to an increase in centralized decisions with inherent decrease in participation.

\subsection{Land as Investment Object}

Investment in farmland in the EU involves a huge diversity of actors. This investment would even lead to the emergence of 'a new asset class made up of large banking groups, as well as pension and insurance funds' [60] (p. 26). Low interest rates make land appear as a safe investment, but other functions and values of land are lost, from local employment to biodiversity to rural society's identification of a landscape as home [5,11]. De Schutter [55] pointed out that the productivity per hectare is lower in large-scale production processes, but their crops are cheap because neither environmental nor social costs are included. For example, the negative impacts on soil and climate.

When land is treated purely as an investment object it might be sold again quickly, compared to traditional turnover in rural areas, in response to capital market opportunities [5]. The impact of such short-term investment and more frequent ownership changes on the agricultural sector are not yet well understood. We assume that without a longer-term engagement, there is not much involvement in social activities or efforts to become part of rural communities.

Yet this negative impact has to be qualified in one respect. Anecdotal evidence shows that farmers often call in 'their' related investors, if a plot of farmland that they lease is about to be sold. They ask their investor to buy it and in exchange, for arranging the deal to continue the lease with them. Tietz [92] (p. 23) calls these actors 'local farmers who have investors with minority interest'. Thus, for the surrounding community nothing will change for a medium-time, although the underlying ownership structure of land changed. It is an open question if the hidden LSLAs should be called land grabbing, since at first sight, they have few negative consequences.

\subsection{Decision Power Concentration}

Finally, it is significant that in Europe and also in Germany, most of the local planning processes, land consolidation processes, flood-protection programs, and all planning and civic participation in infrastructure projects are tied to land ownership and the owner may or may not call upon the farmer-tenant to get involved. With ownership concentrated in the hands of a few, these few monopolize most of the decisions about the development of the village (in some villages the concentration process appears like a reintroduction of feudalism, with one influential family running things [107]. The family sponsors the sports club and is involved in all kinds of local activities but on the other hand all decisions seem to be taken in accordance with it). 
The fear that this is going to happen is also described by Mamonova [14] who shows for rural Ukraine how small land owners instead of selling, just rent out their plots to retain some decision-making power. Hall et al. [63] turns out to be relevant here as one form of excluding others from decisions is by 'legitimation,' in this case by land ownership. Another notable example is Scotland, where about $30 \%$ of private land is owned by 115 landowners [69]. McKee [32] showed that these landowners exert remarkable influence in rural communities.

Mamonova [108] (p. 15) described that among Ukrainian villagers' discontent with large-scale agribusiness grew with the political changes in the country: 'Many villagers began to identify large-scale land investments as 'land grabbing', and openly criticized extractivist activities of agribusiness and its control over the state.' The rural inhabitants started to foster small-scale agriculture, which Mamonova connected to growing patriotism; also the growing wish for food sovereignty with the desire to gain more control over food production.

Focusing on extractive activities, the dealing with added value is discussed by several scholars [1,44,109], examining 'the purposes of resource extraction geared towards external consumers' [109] (p. 901). German law forbids the sale of agricultural land to non-agricultural entrepreneurs, but this can be circumvented by buying the share of a company which owns land. Hence, agricultural land is sold also to non-farmers [68]. This happened to the former fields of KTG Agrar. They were sold to Munich Re, a large reinsurer, by selling a certain share of a subsidiary company [110]. The subsequent critical discussion of farmers, who felt overlooked, led to a reaction of the municipalities. For example, Brandenburg started to withdraw its permits for local land deals [111].

\subsection{De-Facto Limited Land Market Access}

In the 'power of exclusion framework' [63], market power is described as another means of gaining control. The high prices of land can become barriers preventing local people from accessing the land market and thus land itself.

In our study in Saxony-Anhalt, all interviewed farmers complained about high land prices (for sale or lease), and some even thought that it would not be economically wise to buy land at the current market price, because of uncertainty of whether costs could be met. More than one farmer reported that land was sold to a non-agricultural bidder by the BVVG, and that the buyer was not even aware of the actual soil quality of the land. In contrast, Hüttel et al. [87] found land sale processes, rather than the participation of non-farmers, have most influence in shaping land prices (in particular, open transparent bidding systems, as practiced by the BVVG, lead to price increases [87]. As a lesson learned, BVVG started to sell smaller parcels of land to enable farmers to compete who cannot afford to buy a huge piece of land).

LSLA leads to concentration at the land market, market domination, and hindrance in the functioning of land markets [18]. Constantin et al. [11] described how foreign buyers drive national Romanian buyers off the market, as the latter are not able to afford the prices paid. The fear of losing land to foreigners in this manner was long given as a reason for a moratorium in land markets in many Eastern European post-socialist countries. The fear of losing the production base and thus partly the chance for food sovereignty and security to foreigners suggest a social aspect of land grabbing, too.

\section{Discussion}

To discuss land grabbing in a European context, the manifold values of land need to be reviewed. The fact that land is at large regarded as an investment object and thus, recently increasingly owned from people outside the region, does not necessarily mean there is land grabbing. When land is 'controlled' outside the rural community, it is important to examine what the social consequences in the rural areas are [68] (and, although not the focus of this paper, what the environmental implications are). A corresponding view has been expressed by scholars who point out the process-based nature of land grabbing $[1,61,63]$. We bring these arguments together by emphasizing the amount of exerted 
control, which can be rather subtle. Fundamentally, the conditions of access to land and whether control over land diminishes the social values of land is decisive in identifying land grabbing.

What is similar among cases of LSLA in both developing and developed countries is the likelihood that they are driven by an economic view of reasoning in which land is a commodity. What is of interest to us are the negative social consequences of those transactions. We do, however, not assume that all LSLA necessarily have negative outcomes. Azadi et al. [53] for instance, differentiated clearly between four possible outcomes of LSLA. They include win-win deals with potential to significantly promote the agricultural sector and the rural society of host regions or countries.

Even though this paper is about "Europe" it is not evident what encompasses "Europe". We defined Europe as a western-oriented geographical economic area, but Europe can be thought smaller or bigger e.g., the Land Matrix counts Russia as Eastern Europe; an EU study obviously focuses on the member states of the European Union. We included case studies from Ukraine, which is partly western oriented, but also partly controlled by Russian-friendly forces. Nevertheless, we decided to include Ukraine because we are aware that "Europe" does not stop at the EU border. Neighboring countries, like Serbia and Macedonia, are candidates for EU integration [112].

It is of particular relevance whether and how much farming is connected to contemporary rural societies. If land grabbing means land concentration that has negative side-effects for rural society, the extent of this connection before LSLA occurs is important to examine. This was suggested by previous studies $[13,15,113]$ with a critical view towards the motivation of large-scale investors. The skepticism against land acquisitions may even stem from a nationalistic tendency with prejudice towards foreigners $[114,115]$. In our study we did not detect fear of foreign investors, but prejudice against investors from former West Germany. Moreover, the collection of case studies by Franco and Saturnino [13] and other studies $[32,37,108,116]$ suggest that farming is desired in agricultural areas, but often the main problem would be an adequate access to land. Yet, there are general observations about rural-urban migration, where the rural areas provide less jobs [79,83], another explanation could be that there is a decline of interest in agricultural processes [117]. Our study showed that non-farmer rural inhabitants consider agriculture as important for their village, but they lack insights of agricultural production. Furthermore, the interviewed farmers are fond of their lifestyle and regard the availability of acquiring or leasing land as the basis for their enterprise. Studies about land grabbing suggest, that large investors do not seek a certain rural lifestyle, but security for capital investments [47,49,113]. Geisler [113] even calls these trophy lands. Overall, we find that there is a declining affinity to farming in rural areas but still an interest in agricultural processes.

When speaking about societal effects of LSLA, there is a focus on rural areas. The meaning of rural areas for society is a topic widely discussed in fields like geography or rural sociology. Although rural society is no longer very much aligned with the agricultural sector, nonetheless when we asked members of the rural societies about their associations for the term 'land', 16.7\% of 114 respondents still answered 'field', followed by 'soil' (11.9\%) and 'home' (7.1\%). The latter, in particular, is a strong signal that land involves intrinsic values difficult to express in monetary terms and easily ignored in frequent land transactions. When freely associating, only three out of 134 words stated by respondents referred to a monetary value of land. We also found a strong indicator that rural inhabitants appreciate a special recreation use-value of land: $58.9 \%$ of interviewees claim that they associate 'tranquility' (In German: Ruhe) with the notion of rural life. Interestingly, the associated 'tranquillity' was also mentioned by rural inhabitants who live next to a military training area with shooting ranges or those who live next to a bigger road or a farm in harvest season. Thus, 'tranquillity' might also be a perceived way of life, then merely an actual description of an acoustic level. This opens new perspectives about the interpretation of respondent's perceptions and could even lead to a philosophical discussion.

We also need to notice who is actually cultivating owned and leased land in East Germany. Particularly with an East German tenancy rate of $71 \%$, the landowner is not the one who is actually cultivating the land [18]. If the land is leased, the tenant can additionally swap the fields with another farmer to make the farm cohesive. Given these three layers-owners, tenants and cultivators-the 
important factor is how control over land is exerted. Large-scale agriculture is not necessarily negative for rural development. East Germany's history of agricultural structure shows that large farm units differed very much from the smaller family farms in Western Germany but were likewise part of the rural community. However, as Laschewski [24] (p. 17) contended, 'general processes of peripherization' are afflicting rural areas in East Germany with a slow economy and rural-urban migration. At the same time, there are exceptions especially in areas around larger cities like Berlin or Potsdam, there is influx of new inhabitants to rural areas accompanied by increasing prices for housing and fueling of the rural economy. In Germany, these areas are called "Speckgürtel", which describes the sprawl of suburbs. The processes of pheriperization and suburbanization also apply to the European countryside. It must be noted that LSLA intensifies those developments, and therefore has negative effects.

Even though our case study cannot be representative for whole Germany or Europe, the findings are an indicator of villager's relationship to agricultural production in Saxony-Anhalt. As we mentioned earlier, moderatum generalization can be drawn from qualitative data and it needs more case studies from Europe about LSLA to integrate our findings with insights from other studies.

\section{Conclusions}

When estimating socially negative effects of an agricultural land transaction, it is not of foremost importance who actually owns the land. A local tenant with secure long-term rights could care as much for the land as an actual owner [29,31]. However, it is important how (visible) farmers shape the rural life and environmental landscape by their social and agricultural activities. We suggest six criteria to judge on the interdependencies between LSLA and social implications in rural areas in Europe: legal irregularities, non-residence, centralization in decision-making structures, land as investment object, decision-power concentration, and de-facto limited land market access. Pursuing these criteria allows a first indication of whether to 'label' the disadvantageous consequences of LSLA affecting rural people in European industrialized countries as land grabbing, and therewith advance that term as a sociological concept. LSLA and ownership change can have negative side-effects, such as aesthetical changes of rural areas due to standardized size-dependent production processes, leading to a different local perception of agricultural landscapes and even a loss of identity. In many European countries, as in Germany, ownership itself qualifies to participate in local decision-making. Likewise, LSLA and the related further land concentration mean also a centralized decision-making, which leaves less agency for the villagers. De-facto access to land is also an issue, when an average farmer has a lesser chance to buy agricultural land due to raising prices or too large plots offered, when confronted with capital-intensive investors with or without agricultural background and sometimes not even coming from the region. Finally, in Europe land acquisitions can be accompanied also to some extent by irregularities in contracts.

Only if we are able to address the effect of LSLA more systematically-possibly leading to discontent of rural people, an increase in migration, social injustice, or hardship-can an argument for political action be drawn. Because not all kinds of LSLA are negative, the consequences of LSLA must be considered carefully. Agricultural structural change happens even without these land transactions; but if LSLA pushes current processes of agricultural structural change too far, this could be a normative justification for political action. We showed that, in turn, neither hot spot conflicts nor objective measurable impacts, but rather social subtle effects are what make up a land-grab effect in Europe. When we reach the conclusion that the phenomenon we observe, including the described negative consequences, is land grabbing, and if society's concerns push politicians to control land transactions, a broad social discourse is still needed. Societies must debate whether such aims can be placed above the prevailing property order in democratic industrialized countries. For instance, in Germany, steering land deals in a government-preferred direction is in conflict with the German constitution $(\S 14)$ that protects the freedom to sell private property. Thus, state intervention would require careful legal considerations in other European countries, too, with similar systems of property ownership. 
Author Contributions: R.B. conducted the empirical work, analyzed the data and wrote the paper. R.B. and I.T. elaborated jointly the study design. I.T. contributed to the theoretical and conceptual foundations.

Funding: We acknowledge the financial support within the funding program Open Access Publishing by the German Research Foundation (DFG).

Conflicts of Interest: The authors declare no conflict of interest.

\section{References}

1. Borras, S.M., Jr.; Franco, J.C. Global land grabbing and trajectories of agrarian change: A preliminary analysis. J. Agrar. Chang. 2012, 12, 34-59. [CrossRef]

2. Cotula, L. The international political economy of the global land rush: A critical appraisal of trends, scale, geography and drivers. J. Peasant Stud. 2012, 39, 649-680. [CrossRef]

3. Dell'Angelo, J.; D'Odorico, P.; Rulli, M.; Marchand, P. The tragedy of the grabbed commons: Coercion and dispossession in the global land rush. World Dev. 2017, 92, 1-12. [CrossRef]

4. Baird, I. Resistance and Contingent Contestations to Large-Scale Land Concessions in Southern Laos and Northeastern Cambodia. Land 2017, 6, 16. [CrossRef]

5. Gunnoe, A. The Political Economy of Institutional Landownership: Neorentier Society and the Financialization of Land. Rural Sociol. 2014, 79, 478-504. [CrossRef]

6. Ince, O.U. Primitive accumulation, new enclosures, and global land grabs: A theoretical intervention. Rural Sociol. 2014, 79, 104-131. [CrossRef]

7. White, B.; Borras, S.M., Jr.; Hall, R.; Scoones, I.; Wolford, W. The new enclosures: Critical perspectives on corporate land deals. J. Peasant Stud. 2012, 39, 619-647. [CrossRef]

8. Zoomers, A. Globalisation and the foreignisation of space: Seven processes driving the current global land grab. J. Peasant Stud. 2010, 37, 429-447. [CrossRef]

9. D'Odorico, P.; Rulli, M.C.; Dell'Angelo, J.; Davis, K.F. New frontiers of land and water commodification: Socio-environmental controversies of large-scale land acquisitions. Land Degrad. Dev. 2017, 28, 2234-2244. [CrossRef]

10. Baird, I.; Fox, J. How Land Concessions Affect Places Elsewhere: Telecoupling, Political Ecology, and Large-Scale Plantations in Southern Laos and Northeastern Cambodia. Land 2015, 4, 436. [CrossRef]

11. Constantin, C.; Luminița, C.; Vasile, A.J. Land grabbing: A review of extent and possible consequences in Romania. Land Use Policy 2017, 62, 143-150. [CrossRef]

12. Endres, A. Europas neue Großgrundbesitzer. Available online: http:/ / www.zeit.de/wirtschaft/2013-04/ landkonzentration-landgrabbing-europa (accessed on 28 June 2017).

13. Franco, J.; Saturnino, B.J. Land Concentration, Land Grabbing and People's Struggles in Europe; Transnational Institute: Amsterdam, The Netherlands, 2013.

14. Mamonova, N. Resistance or adaption? Ukrainian pesants' response to large-scale land aquisitions. J. Peasant Stud. 2015, 42, 607-634. [CrossRef]

15. van der Ploeg, J.D.; Franco, J.C.; Borras, S.M., Jr. Land concentration and land grabbing in Europe: a preliminary analysis. Can. J. Dev. Stud. 2015, 36, 147-162. [CrossRef]

16. Teklemariam, D.; Azadi, H.; Nyssena, J.; Haile, M.; Witlox, F. Transnational land deals: Towards an inclusive land governance framework. Land Use Policy 2015, 42, 781-789. [CrossRef]

17. Crisp, R. Well-Being. Available online: https://plato.stanford.edu/entries/well-being/ (accessed on 12 July 2018).

18. BMEL. Agrarpolitischer Bericht der Bundesregierung 2015; BMEL: Berlin, Germany, 2015.

19. Henrichsmeyer, W.; Witzke, H.P. Agrarpolitik Band 2; Ulmer Verlag: Stuttgart, Germany, 1994.

20. Weingarten, P. Agrarpolitik in Deutschland. Politik und Zeitgeschichte 2010, 5, 6-17.

21. Wilson, G.A.; Dünckmann, F. From "weak" to "strong" multifunctionality? A research framework for assessing farm-level multifunctional pathways in the UK and Germany. Rural 2009, 3, 15-34.

22. Laschewski, L.; Penker, M. Editorial. Rural change and the revalorisation of rural property objects. Inter. J. Agri. Resour. Gov. Ecol. 2009, 8. [CrossRef]

23. European Commission. Glossary: Agriculture and Landscape. Available online: http://ec.europa.eu/ agriculture/envir/landscape/index_en.htm (accessed on 2 May 2016). 
24. Laschewski, L. Rural Restructuring and Conflicting Definitons of the Rural (Problem) in East Germany; BTU Cottbus-Senftenberg: Cottbus, Brandenburg, Germany, 2014.

25. Alden Wily, L. Collective Land Ownership in the 21st Century: Overview of Global Trends. Land 2018, 7, 68. [CrossRef]

26. Penalver, E.M. Land Virtues. Cornell Law Rev. 2009, 94, 821-888.

27. Mishra, K.; Sam, A.G. Does Women's Land Ownership Promote Their Empowerment? Empirical Evidence from Nepal. World Dev. 2016, 78, 360-371. [CrossRef]

28. Schlager, E.; Ostrom, E. Property-Rights Regimes and Natural Resources: A Conceptual Analysis. Land Econ. 1992, 68, 249-262. [CrossRef]

29. Meinzen-Dick, R. Property rights and sustainable irrigation: A developingcountry perspective. Agric. Water Manag. 2014, 145, 23-31. [CrossRef]

30. Ellickson, R. Order without Law. How Neighbors Settle Disputes; Harvard University Press: Cambridge, UK, 1991.

31. Loehr, D. Capitalization by formalization?-Challenging the current paradigm of land reforms. Land Use Policy 2012, 29, 837-845. [CrossRef]

32. McKee, A.J. Legitimising the Laird? Communicative Action and the role of private landowner and community engagement in rural sustainability. J. Rural Stud. 2015, 41, 23-36. [CrossRef]

33. Lengen, C.; Gebhard, U. Zum Identitätsbegriff. In Landschaft, Identität und Gesundheit; Gebhard, U., Kistemann, T., Eds.; Springer: Wiesbaden, Germany, 2016; pp. 45-62.

34. Salamon, S. From hometown to nontown: Rural community effects of suburbanization. Rural Sociol. 2003, 68, 1-24. [CrossRef]

35. Verderey, K. The Vanishing Hectare; Cornell University Press: Ithaka, NY, USA, 2003.

36. Bromley, J.E. German Reunification: Unfinished Business; Routledge: Abington, UK, 2017.

37. Preissel, S.; Zander, P.; Knierim, A. Sustaining Farming on Marginal Land: Farmers' Convictions, Motivations and Strategies in Northeastern Germany. Sociologia Ruralis 2017, 57, 682-708. [CrossRef]

38. Petrescu-Mag, R.M.; Petrescu, D.C.; Petrescu-Mag, I.V. Whereto land fragmentation-Land grabbing in Romania? The place of negotiation in reaching win-win community-based solutions. Land Use Policy 2017, 64, 174-185. [CrossRef]

39. Goldschmidt, W. As you sow: Three studies in the social consequences of agribusiness; Allanheld, Osmun \& Co. Publishers: Montclair, NJ, USA, 1978.

40. Lobao, L.; Meyer, K. The Great Agricultural Transition: Crisis, Change, and Social Consequences of Twentieth Century US Farming. Annu. Rev. Sociol. 2001, 27, 103-124. [CrossRef]

41. Lobao, L.M.; Schulman, M.D.; Swanson, L.E. Still Going: Recent Debates on the Goldschmidt Hypothesis1. Rural Sociol. 1993, 58, 277-288. [CrossRef]

42. Parkins, J. Industrial Agriculture and Community Outcomes: A Preliminary Study of Goldschmidt's Hypothesis in Rural Canada; University of Alberta: Edmonton, AB, Canada, 2015.

43. Fairhead, J.; Leach, M.; Scoones, I. Green Grabbing: A new appropriation of nature? J. Peasant Stud. 2012, 39, 237-261. [CrossRef]

44. Evangelia, A.; William, M.A. Neoliberal Capitalism and Conservation in the Post-crisis Era: The Dialectics of "Green" and "Un-green" Grabbing in Greece and the UK. Antipode 2015, 47, 15-35. [CrossRef]

45. Harvey, D. The 'new' imperialism: Accumulation by disposession. Soc. Regist. 2004, 40, 63-87.

46. Deininger, K. Challenges posed by the new wave of farmland investment. J. Peasant Stud. 2011, 38, $217-247$. [CrossRef]

47. Deininger, K.; Byerlee, D. Rising Global Interest in Farmland; The World Bank: Washington, DC, USA, 2011.

48. Margulis, M.E.; McKoen, N.; Borras, S.M., Jr. Land Grabbing and Global Governance: Critical Perspectives. Globalizations 2013, 10, 1-23. [CrossRef]

49. Von Braun, J.; Meinzen-Dick, R. "Land grabbing” by foreign investores in developing countries: risks and oppertunities. In IFPRI Policy Brief; International Food Policy Research Institute: Washington, DC, USA, 2009; Volume 13, pp. 1-9.

50. McMichael, P. Rethinking land grab ontology. Rural Sociol. 2014, 79, 34-55. [CrossRef]

51. The Land Matrix Global Observatory. Get the Detail: By Target Region. Available online: www.landmatrix. org (accessed on 22 February 2018). 
52. Theesfeld, I. The Impacts of Liberalized Land Markets on the Resource Water: A Property Rights Approach. In Schriften der Gesellschaft für Wirtschafts- und Sozialwissenschaften des Landbaus e. V.; Landwirtschaftsverlag GmbH: Gießen, Germany, 2016; Volume 51, pp. 355-366.

53. Azadi, H.; Houshyar, E.; Zarafshani, K.; Hosseininia, G.; Witlox, F. Agricultural outsourcing: A two-headed coin? Glob. Planet. Chang. 2013, 100, 20-27. [CrossRef]

54. International Land Coalition. Tirana Declaration "Securing Land Access for the Poor in Times of Intensified Natural Resources Competition"; Global Assembly: Tirana, Albania, 2011.

55. De Schutter, O. How not to think of land-grabbing: three critiques of large-scale investments in farmland. J. Peasant Stud. 2011, 38, 249-279. [CrossRef]

56. FAO. Voluntary Guideline on the Responsible Governance of Tenure of Land, Fisheries and Forests in the Context of National Food Security; Food and Agriculture Organization of the United Nations: Rome, Italy, 2012.

57. World Bank; FAO; IFAD; UNCTAD. The Principles for Responsible Agricultural Investment (PRAI). Available online: http:/ / unctad.org/en/Pages/DIAE/G-20/PRAI.aspx (accessed on 6 July 2017).

58. Borras, S.M., Jr.; Hall, R.; Scoones, I.; White, B.; Wolford, W. Towards a better understanding of global land grabbing: an editorial introduction. J. Peasant Stud. 2011, 38, 209-216. [CrossRef]

59. Makki, F. Development by dispossession: Terra nullis and the social-ecology of new enclosues in Ethiopia. Rural Sociol. 2014, 79, 79-103. [CrossRef]

60. Kay, S.; Peuch, J.; Franco, J. Directorate-General for Internal Policies Policy Department B: Structural and cohesion policies. In Extend of Farmland Grabbing in the EU; Agriculture and Rural Development: Brussels, Belgium, 2015.

61. Friis, C.; Nielsen, J.Ø. Small-scale land acquisitions, large-scale implications: Exploring the case of Chinese banana investments in Northern Laos. Land Use Policy 2016, 57, 117-129. [CrossRef]

62. Borras, S.M., Jr.; Franco, J.; Gómez, S.; Kay, C.; Spoor, M. Land grabbing in Latin America and the Caribbean. J. Peasant Stud. 2012, 39, 845-872. [CrossRef]

63. Hall, D.; Hirsch, P.; Li, T. Powers of Exclusion: Land Dilemmas in Southeast Asia; University of Hawai'i Press: Honolulu, HI, USA, 2011.

64. World Bank. Europäische Union: Verteilung der Erwerbstätigen auf die Wirtschaftssektoren in den Mitgliedsstaaten im Jahr 2014. Available online: https: / de.statista.com/statistik/daten/studie/249086/ umfrage/erwerbstaetige-nach-wirtschaftssektoren-in-den-eu-laendern/ (accessed on 20 February 2017).

65. Forstner, B.; Tietz, A. Kapitalbeteiligung Nichtlandwirtschaftlicher und überregional Ausgerichteter Investoren an Landwirtschaftlichen Unternehmen in Deutschland; Johann Heinrich von Thünen-Institut: Braunschweig, Germany, 2013.

66. Antonelli, M.; Siciliano, G.; Turvani, M.E.; Rulli, M. Global investments inagricultural land and the role of the EU: Drivers, scope and potential impacts. Land Use Policy 2015, 47, 98-111. [CrossRef]

67. Fidrich, R. The return of the White Horse: Land grabbing in Hungary. In Land Concentration, Land Grabbing and People's Struggles in Europe; Franco, J., Borras, S., Jr., Eds.; Transnational Institute: Amsterdam, The Netherlands, 2013.

68. Tietz, A. Überregional Aktive Kapitaleigentümer in Ostdeutschen Agrarunternehmen: Entwicklungen bis 2017; Johann Heinrich von Thünen-Institut: Braunschweig, Germany, 2017.

69. Wightman, A. The Poor Had No Lawyers; Birlinn Limited: Edinburgh, UK, 2013.

70. Stewart, C.; D'Amore, A. Land Prices Vary Considerably between and within Member States. Eurostat Press Release 21.03.2018, Luxembourg. Available online: http:/ / ec.europa.eu/eurostat/documents/2995521/ 8756523/5-21032018-AP-EN.pdf/b1d0ffd3-f75b-40cc-b53f-f22f68d541df (accessed on 16 August 2018).

71. Swain, N. Agriculture 'East of the Elbe' and the Common Agricultural Policy. Sociologia Ruralis 2013, 53, 369-389. [CrossRef]

72. Jochimsen, H. 20 Jahre grüner Aufbau Ost. Berichte über Landwirtschaft 2010, 88, 203-247.

73. Laschewski, L. Der Umbau der ländlichen Gesellschaft in den Neuen Bundesländern. Land-Berichte 2009, 3 , 73-94.

74. Hübner, H. Allgemeiner Teil des Bürgerlichen Gesetzbuches; Walter de Gruyter \& Co.: Berlin, Germany, 1995.

75. Martens, B. Landwirtschaft in Ostdeutschland: der späte Erfolg der DDR; Bundeszentrale für Politische Bildung: Berlin, Germany, 2010. 
76. Jantsch, A.; Wunder, C.; Hirschauer, N. Lebensqualität in Deutschland. Ein Vergleich von städtischen und ländlichen Regionen. In 56. Jahrestagung der Gesellschaft für Wirtschafts- und Sozialwissenschaften des Landbaues e.V.; GEWISOLA: Bonn, Germany, 2016.

77. Statistisches Bundesamt. Arbeitsmarkt. Registrierte Arbeitslose, Arbeitslosenquote nach Gebietsstand. Available online: https:/ / www.destatis.de/DE/ZahlenFakten/Indikatoren/LangeReihen/Arbeitsmarkt/ lrarb003.html (accessed on 5 February 2017).

78. Pfusterschmid, S. Landwirtschaft und Gesellschaft. Lernweltforschung 2016, 18, 297-313. [CrossRef]

79. Specht, J.; Wenz, K.; Häring, A.M.; Braun, C.L. Wandel im ländlichen Raum: Von Wandlungsprozessen zu neuen Kompetenzbedarfen; Hochschule für Nachhaltige Entwicklung Eberwalde (FH): Eberswalde, Germany, 2013.

80. Knickel, K. Agricultural Structural Change: Impact on the Rural Environment. J. Rural Stud. 1990, 6, $383-393$. [CrossRef]

81. Chavas, J.-P. Structural change in agricultural production: Economics, technology and policy (Chapter 5). Handb. Agric. Econ. 2001, 1, 263-285. [CrossRef]

82. Henkel, G. Das Dorf. Landleben in Deutschland_Gestern und Heute; Bundeszentrale für politische Bildung: Bonn, Germany, 2014.

83. Neu, C. Urbanisierung, Peripherisierung und Landflucht 3.0. Sozialwissenschaftliche Perspektiven auf die Veränderung von Stadt und Land im demographischen Wandel. In Landflucht 3.0. Welche Zukunft hat der Ländliche Raum? Quandt-Stiftung, H., Ed.; Herder: Freiburg, Germany, 2015; pp. 18-33.

84. MULE. Bericht zur Lage der Landwirtschaft des Landes Sachsen-Anhalt 2014; Ministerium für Landwirtschaft und Umwelt des Landes Sachsen-Anhalt: Magdeburg, Germany, 2014.

85. BMEL. Agrarbericht 2000. Agrar-und ernährungspolitischer Bericht der Bundesregierung; Deutscher Bundestag 14; Wahlperiode: Berlin, Germany, 2000.

86. Statistisches Bundesamt. Agrarstrukturerhebung 2016 (Endgültige Ergebnisse): 9600 Landwirtschaftliche Betriebe Weniger als im Jahr 2013. Available online: https://www.destatis.de/DE/ZahlenFakten/ Wirtschaftsbereiche/LandForstwirtschaftFischerei/LandwirtschaftlicheBetriebe/ASE_Aktuell.html (accessed on 4 July 2017).

87. Hüttel, S.; Wildermann, L.; Croonenbroek, C. How do insitutional market players matter in farmland pricing? Land Use Policy 2016, 59, 154-167. [CrossRef]

88. Kagerbauer, S.; Kruspe, H. Bioland kritisiert neue Privatisierungsregeln der BVVG als völlig unzureichend/Positionspapier; Bioland: Greifenhagen/Berlin, Germany, 2015.

89. BVVG. BVVG auf neue Vorgaben ausgerichtet; Bodenverwertungs- und -verwaltungs GmbH: Berlin, Germany, 2016.

90. Schumann, H. Die deutschen Agrarriesen. In Der Tagesspiegel 12.08.2013; Verlag Der Tagesspiegel GmbH: Berlin, Germany, 2013.

91. Siegmund, K. Kaufwerte und Pachtpreise 2013. Kaufpreise teilweise explodiert. Pachten moderater gestiegen. Bodenmarkt 2015, 7, 4-8.

92. Tietz, A. Überregional Aktive Kapitaleigentümer in Ostdeutschen Agrarunternehmen: Bestandsaufnahme und Entwicklung; Thünen Institut für ländliche Räume: Braunschweig, Germany, 2015.

93. Balmann, A. Braucht der ostdeutsche Bodenmarkt eine stärkere Regulierung? Agra Eur. 2015, 13, 1-7.

94. TUBE; NordNordWest. Location Map and Map of Administrative Divisions of Saxony Anhalt; Wikimedia Commons: San Francisco, CA, USA, 2012.

95. Heckathorn, D.D. Snowball versus respondent-driven sampling. Sociol. Methodol. 2011, 41. [CrossRef] [PubMed]

96. Bitsch, V. Qualitative Forschung in der Angewandten Ökonomie. Schwerpunkt: Landwirtschaft; Shaker Verlag: Aachen, Germany, 2011.

97. Bryman, A. Social Research Methods, 4th ed.; Oxford University Press: Oxford, UK, 2012.

98. Favareto, A. The rationalization of rural life. Estudos Sociedade e Agricultura 2006, 2, 9-30. [CrossRef]

99. Mayring, P. On Generalization in Qualitatively Oriented Research. Forum Qualitative Sozialforschung 2007, 8. [CrossRef]

100. Arpe, J. Vertrauen in Deutschland. Eine Qualitative Wertestudie. Zusammenfassung der Ergebnisse; Bertelsmann Stiftung: Gütersloh, Germany, 2009. 
101. Forstner, B.; Tietz, A.; Klare, K.; Kleinhanss, W.; Weingarten, P. Aktivitäten von Nichtlandwirtschaftlichen und überregional Ausgerichteten Investoren auf dem Landwirtschaftlichen Bodenmarkt in Deutschland. Endbericht 2, Aktualisierte Fassung; Johann Heinrich von Thünen-Institut: Braunschweig, Germany, 2011.

102. Grossarth, J. So Kaufte sich die KTG Agrar ihr Eigenes Getreide ab. Available online: http:/ / www.faz.net/aktuell/ finanzen/anleihen-zinsen/mittelstandsanleihen/ktg-agrar-taeuschteueber-jahre-oeffentlichkeit-und-banken-14534275.html (accessed on 28 June 2017).

103. KTG Agrar SE. Gesellschaftliches Engagement. Available online: http://www.ktg-agrar.de/werte/ engagement.html (accessed on 11 May 2018).

104. Deter, A. Niedersachsen Plant Pachtpreisbremse in der Landwirtschaft. Available online: https: / / www.topagrar.com/news/Home-top-News-Niedersachsen-plant-Pachtpreisbremse-in-derLandwirtschaft-3947136.html (accessed on 28 June 2017).

105. MULE. Regierungserklärung: Eine Politik der Verantwortung für eine Zukunftssichere Landwirtschaft. Available online: http://www.presse.sachsen-anhalt.de/index.php?cmd=get\&id=869989\&identifier= c9a34cd53e0e55f1fde08fac58350da1 (accessed on 16 August 2018).

106. Larson, A.M.; Ribot, J.C. Democratic decentralisation through a natural resource lens: an introduction. Eur. J. Dev. Res. 2004, 16, 1-25. [CrossRef]

107. Knigge, A. Ausverkauf der Ostdeutschen Landwirtschaft. Available online: http:/ /www.deutschlandfunk. de/landgrabbing-ausverkauf-der-ostdeutschen-landwirtschaft.724.de.html?dram:article_id=274916 (accessed on 28 June 2017).

108. Mamonova, N. Patriotism and Food Sovereignty: Changes in the Social Imaginary of Small-Scale Farming in Post-Euromaidan Ukraine. Sociologia Ruralis 2018, 58, 190-212. [CrossRef]

109. Visser, O.; Mamonova, N.; Spoor, M. Oligarchs, megafarms and reserves: understanding land grabbing in Russia. J. Peasant Stud. 2012, 29, 899-931. [CrossRef]

110. Herz, C. Der Bauernkrieg der Munich Re. Available online: https://www.handelsblatt.com/finanzen/ banken-versicherungen/rueckversicherer-der-bauernkrieg-der-munich-re/20555670.html (accessed on 11 July 2018).

111. Lehmann, N. Landkreis Wideruft KTG Agrar-Flächendeals. Available online: https://www.agrarheute. $\mathrm{com} / \mathrm{management} / \mathrm{rech} /$ landkreis-wideruft-ktg-agrar-flaechendeals-539980 (accessed on 11 July 2018).

112. Kocjancic, M. EU Enlargement-State of Play. Available online: https:/ / europa.eu/newsroom/highlights / special-coverage/enlargement_en (accessed on 20 July 2018).

113. Geisler, C. Trophy lands: why elites acquire land and why it matters. Can. J. Dev. Stud. 2015, 36, $241-257$. [CrossRef]

114. Tesser, L.M. East-Central Europe's new security concern: foreign land ownership. Communist Post-Communist Stud. 2014, 37, 213-239. [CrossRef]

115. Burger, A. Why is the issue of land ownership still of major concern in East Central European (ECE) transitional countries and particularly in Hungary? Land Use Policy 2006, 23, 571-579. [CrossRef]

116. Kristensen, S.B.P. Agriculture and landscape interaction-landowners' decision-making and drivers of land use change in rural Europe. Land Use Policy 2016, 57, 759-763. [CrossRef]

117. Zander, K.; Isermeyer, F.; Bürgelt, D.; Christoph-Schulz, I.; Salamon, P.; Weible, D. Erwartungen der Gesellschaft an die Landwirtschaft. Abschlussbericht.; Thünen-Institut/Stiftung Westfälische Landwirtschaft: Braunschweig, Germany, 2013.

(c) 2018 by the authors. Licensee MDPI, Basel, Switzerland. This article is an open access article distributed under the terms and conditions of the Creative Commons Attribution (CC BY) license (http://creativecommons.org/licenses/by/4.0/). 